\title{
Repair and Rehabilitation of RCC Beam using Synthetic Fiber Material
}

\author{
M.Hemapriya, T.P.Meikandaan, Anitha K
}

\begin{abstract}
Retrofitting is the alteration of existing structures to make them continuously impenetrable to seismic development, ground development, etc. A large number of the current strengthened solid structures all through the world are in pressing need of recovery, fix or reproduction in light of crumbling because of different factors like consumption, absence of itemizing, disappointment of holding between pillar segment joints and so on. Fiber Reinforced Polymer (FRP) composite has been acknowledged in the development business as a promising substitute for fixing and in augmenting the quality of Reinforced concrete structures. This paper exhibits a test study on fortified solid shafts retrofitted with different kinds of filaments remotely. The goal of this examination is to explore the conduct of shafts in the wake of retrofitting utilizing different normal and engineered filaments including steel strands, polypropylene strands, glass filaments, Basalt filaments, carbon filaments and so forth.
\end{abstract}

Keywords-Epoxy bonding agent, glass fiber, basalt fiber, Repair and Rehabilitation

\section{INTRODUCTION}

Structure may not be a savvy arrangement and it is probably going to turn into an expanded monetary weight if updating is a practical other option[1]-[5]. In such events, fix and restoration are most usually utilized arrangements. Support consumption and auxiliary decay in strengthened cement (RC) structures are normal and incited numerous scientists to look for elective materials and restoration methods. In this unique circumstance, fortifying with Fiber Reinforced Polymers (FRP) composite materials as outer support is of incredible enthusiasm to the Civil designing network. The customary fortifying techniques for fortified solid structures endeavor to repay the lost quality by including progressively material around the current segments. In this way retrofitting and restoration of structures can be finished up to be the best other option[6]-[8].

\section{A. Aim and objective}

- To increase the flexural strength of the beam by using Glass Fiber Mat and Basalt Fiber Mat[9]-[15].

- To analyse the strength before and after using Glass Fiber Mat and Basalt Fiber Mat.

Revised Manuscript Received on October 22, 2019

M.Hemapriya, Department of Civil Engineering, Bharath Institute of Higher Education and Research, Chennai, India. Email: meihemapriya@gmail.com

T.P.Meikandaan, Department of Civil Engineering, Bharath Institute of Higher Education and Research, Chennai , India. Email: ganga_meik@yahoo.co.in

Anitha K , Department of Civil Engineering, Bharath Institute of Higher Education and Research, Chennai , India. Email: anithakrish26@yahoo.co.in

\section{METHODOLOGY}

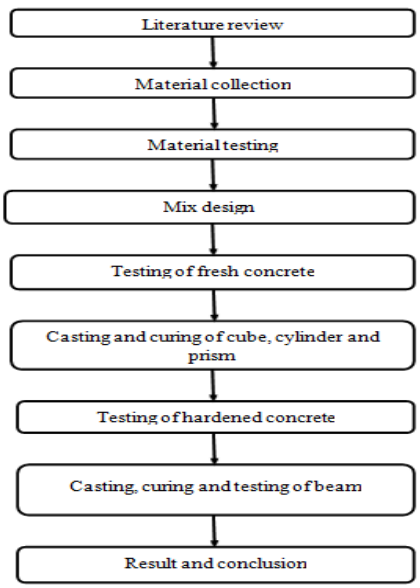

Figure - 1 Flow Chart

\section{MATERIAL PROPERTIES}

Table 1 - Properties of Cement

\begin{tabular}{|c|l|c|}
\hline Sl. No & Properties of cement & Value \\
\hline 1 & Specific Gravity & 3.1 \\
\hline 2 & Normal consistency & $27 \%$ \\
\hline 3 & Fineness & $7.18 \mathrm{gm}$ \\
\hline
\end{tabular}

Table 2 - Properties of Aggregate

\begin{tabular}{|c|l|c|}
\hline Sl. No & \multicolumn{1}{|c|}{ Properties of aggregate } & Value \\
\hline 1 & Specific Gravity of CA & 2.45 \\
\hline 2 & Fineness modulus of CA & 6.77 \\
\hline 3 & Specific Gravity of FA & 2.56 \\
\hline 4 & Fineness modulus of FA & 2.71 \\
\hline
\end{tabular}

Table 3 - Testing of Fresh Concrete

\begin{tabular}{|c|c|c|}
\hline Sl no. & Properties of concrete & Value \\
\hline 1 & Slump Value & $145 \mathrm{~mm}$ \\
\hline 2 & Compaction factor & 0.82 \\
\hline
\end{tabular}

Table 4 - Mix Proportion of M25 grade concrete

\begin{tabular}{|c|c|c|}
\hline $\begin{array}{c}\text { Cement } \\
\left(\mathrm{kg} / \mathrm{m}^{3}\right)\end{array}$ & $\begin{array}{c}\text { Fine Aggregate } \\
\left(\mathrm{kg} / \mathrm{m}^{3}\right)\end{array}$ & $\begin{array}{c}\text { Coarse Aggregate } \\
\left(\mathrm{kg} / \mathrm{m}^{3}\right)\end{array}$ \\
\hline 440 & 909.61 & 741.56 \\
\hline 1 & 2.06 & 1.68 \\
\hline
\end{tabular}




\section{TESTING RESULTS}

Table 5 - Compression Test Results (7 Days)

\begin{tabular}{|c|c|c|c|c|}
\hline S.no & Specimens (mm) & Load $(\mathrm{kN})$ & \begin{tabular}{|c|} 
Compressive strength \\
$\left(\mathrm{N} / \mathrm{mm}^{2}\right)$
\end{tabular} & $\begin{array}{l}\text { Average compressive } \\
\text { strength }\left(\mathrm{N} / \mathrm{mm}^{2}\right)\end{array}$ \\
\hline 1 & Cube 1 & 298 & 13.24 & \multirow{3}{*}{11.59} \\
\hline 2 & Cube 2 & 261 & 11.6 & \\
\hline 3 & Cube 3 & 224 & 9.95 & \\
\hline
\end{tabular}

Table 6 - Split Tensile Test Results (7 Days)

\begin{tabular}{|c|c|c|c|c|}
\hline S.no & Specimens (mm) & Load (KN) & $\begin{array}{c}\text { Split tensile strength } \\
\text { (N/mm2) }\end{array}$ & $\begin{array}{c}\text { Average split tensile strength } \\
(\mathrm{N} / \mathbf{m m} 2)\end{array}$ \\
\hline 1 & Cylinder 1 & 78 & 1.1 & \multirow{3}{*}{0.88} \\
\hline 2 & Cylinder 2 & 62 & 0.87 & \\
\hline 3 & Cylinder 2 & 49 & 0.69 & \\
\hline
\end{tabular}

Table 7 - Flexural Test Results (7 Days)

\begin{tabular}{|c|c|c|c|c|}
\hline S.no & Specimens & Load (KN) & $\begin{array}{c}\text { Flexural strength } \\
\text { (N/mm2) }\end{array}$ & $\begin{array}{c}\text { Average flexural strength } \\
\text { (N/mm2) }\end{array}$ \\
\hline 1 & Prism 1 & 3 & 1.5 & \multirow{2}{*}{10} \\
\cline { 1 - 3 } 2 & Prism 2 & 2 & 1.33 \\
\cline { 1 - 3 } 3 & Prism 3 & 3 & 1.5 & \multicolumn{1}{|c|}{} \\
\hline
\end{tabular}

Table 8 - Compression Test Results (28 Days)

\begin{tabular}{|r|c|c|c|c|}
\hline S.No & $\begin{array}{c}\text { Specimens } \\
(\mathbf{m m})\end{array}$ & Load (kN) & $\begin{array}{c}\text { Compressive strength } \\
\left(\mathbf{N} / \mathbf{m m}^{2}\right)\end{array}$ & $\begin{array}{c}\text { Average Compressive strength } \\
\left(\mathbf{N} / \mathbf{m m}^{2}\right)\end{array}$ \\
\hline 1 & Cube 4 & 534 & 23.7 & \multirow{2}{*}{22.6} \\
\hline 2 & Cube 5 & 475 & 21.1 & \\
\hline 3 & Cube 6 & 524 & 23.2 & \\
\hline
\end{tabular}

Table 9 - Split Tensile Test Results (28 Days)

\begin{tabular}{|l|c|c|c|c|}
\hline S.No & $\begin{array}{c}\text { Specimens } \\
(\mathbf{m m})\end{array}$ & Load $(\mathbf{k N})$ & $\begin{array}{c}\text { Compressive strength } \\
\left(\mathbf{N} / \mathbf{m m}^{2}\right)\end{array}$ & $\begin{array}{c}\text { Average Compressive strength } \\
\left(\mathbf{N} / \mathbf{m m}^{2}\right)\end{array}$ \\
\hline 1 & Cylinder 4 & 107 & 1.51 & \multirow{2}{*}{1.55} \\
\hline 2 & Cylinder 5 & 114 & 1.61 & \\
\hline 3 & Cylinder 6 & 110 & 1.55 & \\
\hline
\end{tabular}

Table 10 - Flexural Test Results (28 Days)

\begin{tabular}{|c|c|c|c|c|}
\hline S.No & $\begin{array}{c}\text { Specimens } \\
(\mathbf{m m})\end{array}$ & Load (kN) & $\begin{array}{c}\text { Compressive strength } \\
\left(\mathbf{N} / \mathbf{m m}^{\mathbf{2}}\right)\end{array}$ & $\begin{array}{c}\text { Average Compressive strength } \\
\left(\mathbf{N} / \mathbf{m m}^{\mathbf{2}}\right)\end{array}$ \\
\hline 1 & Prism 4 & 6 & 3 & \multirow{2}{*}{1.55} \\
\cline { 1 - 3 } 2 & Prism 5 & 4 & 2 & \multirow{2}{*}{1.5} \\
\hline 3 & Prism 6 & 3 & 1.5 & \\
\hline
\end{tabular}

\section{A. Conventional Beam Mould Calculation}

Volume of the beam $=1 \times 0.15 \times 0.15 \mathrm{~m}=0.0225 \mathrm{~m} 3$

Assume load $=50 \mathrm{KN} / \mathrm{m}$

Bending moment $=\mathrm{wl} 2 / 8($ simply supported $)=6.25 \times 106$ $\mathrm{N} / \mathrm{m} 2$

Shear force $=\mathrm{wl} / 2=25 \mathrm{KN}$

$\mathrm{Mu}=0.138 \times$ fck $\mathrm{x}$ bd $2 \mathrm{Mu} /(0.138$ fck $\mathrm{x} \mathrm{b})=\mathrm{d} 2$

$\mathrm{d}=115 \mathrm{~mm}$

Ast calculation

$\mathrm{Mu}=0.87 \times$ fy $\mathrm{x}$ Ast $\mathrm{x}$ d[(1-Ast $\mathrm{x}$ fy) $/$ (bd fck) $]$

$6 \times 106=0.87 \times 415 \times$ Ast $\times 115[1-9.6 \times 10-4$ Ast $]$

$6 \times 106=41520$ Ast -39.85 Ast2

Ast $=173.35 \mathrm{~mm} 2$ Assume $12 \mathrm{~mm}$ dia bars

ast $=\Pi \mathrm{d} 2 / 4$

$=\Pi \times 122 / 4$

$=113.09$

Ast $/$ ast $=173.35 / 113.09$

$=1.53$
2 Nos of $12 \mathrm{~mm}$ dia

Table 11 - Load deflection test on Conventional Beam 1

\begin{tabular}{|c|c|c|c|}
\hline S.NO & Proving Ring Reading & Load $(\mathrm{kN})$ & Deflection (mm) \\
\hline 1 & 10 & 4 & 0.12 \\
\hline 2 & 20 & 8 & 0.34 \\
\hline 3 & 30 & 12 & 0.49 \\
\hline 4 & 40 & 16 & 0.66 \\
\hline 5 & 50 & 20 & 0.85 \\
\hline 6 & 60 & 24 & 0.98 \\
\hline 7 & 70 & 28 & 1.20 \\
\hline 8 & 80 & 32 & 1.37 \\
\hline 9 & 86 & 34.4 & 1.64 \\
\hline
\end{tabular}

Table 12 - Load deflection test on Conventional Beam 2

\begin{tabular}{|c|c|c|c|}
\hline S.No & Proving Ring Reading & Load (kN) & Deflection (mm) \\
\hline 1 & 10 & 4 & 0.14 \\
\hline 2 & 20 & 8 & 0.25 \\
\hline 3 & 30 & 12 & 0.41 \\
\hline 4 & 40 & 16 & 0.67 \\
\hline 5 & 50 & 20 & 0.88 \\
\hline 6 & 60 & 24 & 1.19 \\
\hline 7 & 70 & 28 & 1.37 \\
\hline 8 & 79 & 31.6 & 1.53 \\
\hline
\end{tabular}

Table 13 - Load deflection test on Conventional Beam 1 after Retrofitting Using Glass Fiber Mat

\begin{tabular}{|c|c|c|c|}
\hline S.No & Proving Ring Reading & Load (kN) & Deflection (mm) \\
\hline 1 & 10 & 4 & 0.04 \\
\hline 2 & 20 & 8 & 0.25 \\
\hline 3 & 30 & 12 & 0.49 \\
\hline 4 & 40 & 16 & 0.78 \\
\hline 5 & 50 & 20 & 0.93 \\
\hline 6 & 60 & 24 & 1.15 \\
\hline 7 & 70 & 28 & 1.28 \\
\hline 8 & 80 & 32 & 1.30 \\
\hline 9 & 90 & 36 & 1.53 \\
\hline 10 & 100 & 40 & 1.65 \\
\hline 11 & 110 & 44 & 1.78 \\
\hline 12 & 118 & 47.2 & 1.81 \\
\hline
\end{tabular}

\section{CONCLUSION}

In this preliminary assessment the flexural direct of sustained strong bars remotely fortified by means of carbon, glass, steel, coir and polypropylene sheets are thought about. From the test results and decided quality characteristics, the going with closes are drawn[25]-[29]:

The diversions of the bars are limited because of full folding strategy over all the four sides of the shaft.

The underlying splits in the fortified shafts show up at a higher burden contrasted with the un-reinforced control pillar. The flexural quality and extreme burden limit of the bars improved because of outer

\section{Published By:}

Blue Eyes Intelligence Engineering 
fortifying of bars. The fortifying of bars utilizing fiber sheets is seen as progressively compelling in improving the flexural quality and extreme burden limit of bars[31]-[34]

A definitive burden limit of the bars fortified utilizing fiber sheets is expanded when contrasted with that of control pillar.

\section{REFERENCES}

1. Iyappan L., Dayakar P., Identification of landslide prone zone for coonoortalukusing spatial technology, International Journal of Applied Engineering Research,V-9,I-22,PP-5724-5732,Y-2014.

2. Kumar J., Sathish Kumar K., Dayakar P.,Effect of microsilica on high strength concrete, International Journal of Applied Engineering Research,V-9,I-22,PP-5427-5432,Y-2014.

3. Dayakar P., Vijay Ruthrapathi G., Prakesh J., Management of bio-medical waste, International Journal of Applied Engineering Research,V-9,I-22,PP-5518-5526,Y-2014.

4. Swaminathan N., Dayakar P., Resource optimization in construction project, International Journal of Applied Engineering Research,V-9,I-22,PP-5546-5551,Y-2014.

5. Venkat Raman K., Dayakar P., Raju K.V.B.,An experimental study on effect of cone diameters in penetration test on sandy soil, International Journal of Civil Engineering and Technology,V-8,I-8,PP-1581-1588,Y-2017.

6. Saritha B., Chockalingam M.P.,Photodradation of malachite green DYE using TIO2/activated carbon composite,International Journal of Civil Engineering and Technology,V-8,I-8,PP-156-163,Y-2017

7. Shendge R.B., Chockalingam M.P., Saritha B., Ambica A.,Swat modelling for sediment yield: A case study of Ujjani reservoir in Maharashtra, India,International Journal of Civil Engineering and Technology,V-9,I-1,PP-245-252,Y-2018

8. Chockalingam M.P., Balamurgan V.,Modernisation of an existing urban road-sector in Chennai, a case study report,International Journal of Civil Engineering and Technology,V-8,I-8,PP-1457-1467,Y-2017

9. Saritha B., Chockalingam M.P.,Adsorption study on removal of basic dye by modified coconut shell adsorbent, International Journal of Civil Engineering and Technology,V-8,I-8,PP-1370-1374,Y-2017

10. Saritha B., Chockalingam M.P.,Adsorptive removal of heavy metal chromium from aqueous medium using modified natural adsorbent,International Journal of Civil Engineering and Technology,V-8,I-8,PP-1382-1387,Y-2017

11. Chockalingam M.P., Palanivelraja S.,Retrospective analysis of a theoretical model used for forecasting future air quality near the north Chennai thermal power plant,International Journal of Civil Engineering and Technology,V-8,I-8,PP-1457-1467,Y-2017

12. Saritha B., Chockalingam M.P.,Photodegradation of methylene blue dye in aqueous medium by $\mathrm{Fe}-\mathrm{AC} / \mathrm{TiO} 2$ Composite,Nature Environment and Pollution Technology,V-17,I-4,PP-1259-1265,Y-2018

13. Shendge R.B., Chockalingam M.P., Kaviya B., Ambica A.,Estimates of potential evapotranspiration rates by three methods in upper Bhima Basin, In Maharashtra, India,International Journal of Civil Engineering and Technology,V-9,I-2,PP-475-480,Y-2018

14. Shendge R.B., Chockalingam M.P.,The soil and water assessment tool for Ujjani Reservoir,International Journal of Mechanical Engineering and Technology,V-9,I-2,PP-354-359,Y-2018

15. Shendge R.B., Chockalingam M.P.,A review on soil and water assessment tool,International Journal of Mechanical Engineering and Technology,V-9,I-2,PP-347-353,Y-2018

16. Sachithanandam P., Meikandaan T.P., Srividya T.,Steel framed multi storey residential building analysis and design,International Journal of Applied $\quad$ Engineering Research,V-9,I-22,PP-5527-5529,Y-2014

17. Meikandaan T.P., Ramachandra Murthy A.,Study of damaged RC beams repaired by bonding of CFRP laminates,International Journal of Civil Engineering and Technology,V-8,I-2,PP-470-486,Y-2017

18. Meikandaan T.P., Ramachandra Murthy A.,Retrofittng of reinforced concrete beams using GFRP overlays,International Journal of Civil Engineering and Technology,V-8,I-2,PP-423-439,Y-2017

19. Meikandaan T.P., Ramachandra Murthy A.,Flexural behaviour of RC beam wrapped with GFRP sheets,International Journal of Civil Engineering and Technology,V-8,I-2,PP-452-469,Y-2017
20. Meikandaan T.P., Murthy A.R.,Experimental study on strengthening of rc beams using glass Fiber,International Journal of Civil Engineering and Technology,V-9,I-11,PP-959-965,Y-2018

21. Meikandaan T.P., Hemapriya M.,Use of glass FRP sheets as external flexural reinforcement in RCC Beam,International Journal of Civil Engineering and Technology,V-8,I-8,PP-1485-1501,Y-2017

22. Saraswathy R., Saritha B.,Planning of integrated satellite township at Thirumazhisai,International Journal of Applied Engineering Research,V-9,I-22,PP-5558-5560,Y-2014

23. Saritha B., Ilayaraja K., Eqyaabal Z.,Geo textiles and geo synthetics for soil reinforcement,International Journal of Applied Engineering Research,V-9,I-22,PP-5533-5536,Y-2014

24. Ambica A., Saritha B., Changring G., Singh N B., Rajen M., Salman Md.,Analysis of groundwater quality in and around Tambaram taluk, Kancheepuram district,International Journal of Civil Engineering and Technology,V-8,I-8,PP-1362-1369,Y-2017

25. Arunya A., Sarayu K., Ramachandra Murthy A., Iyer N.R.,Enhancement of durability properties of bioconcrete incorporated with nano silica,International Journal of Civil Engineering and Technology,V-8,I-8,PP-1388-1394,Y-2017

26. Ilayaraja K., Krishnamurthy R.R., Jayaprakash M., Velmurugan P.M., Muthuraj S.,Characterization of the 26 December 2004 tsunami deposits in Andaman Islands (Bay of Bengal, India),Environmental

Sciences, V-66,I-8,PP-2459-2476,Y-2012

27. Ilayaraja K.,Morphometric parameters of micro watershed in Paravanar sub-basin, Cuddalore District,International Journal of Civil Engineering and Technology,V-8,I-8,PP-1444-1449,Y-2017

28. Ilayaraja K., Singh R.K., Rana N., Chauhan R., Sutradhar N.,Site suitability assessment for residential areas in south Chennai region using remote sensing and GIS techniques, International Journal of Civil Engineering and Technology,V-8,I-8,PP-1468-1475,Y-2017

29. Ilayaraja K., Reza W., Kumar V., Paul S., Chowdhary R.,Estimation of land surface temperature of Chennai metropolitan area using Landsat images, International Journal of Civil Engineering and Technology,V-8,I-8,PP-1450-1456,Y-2017

30. Chitra R.,Experimental study on beam using steel fiber and latex,International Journal of Civil Engineering and Technology,V-8,I-8,PP-1395-1403,Y-2017

31. Chitra R.,Analysis of traffic and management at Kovilambakkam intersection,International Journal of Civil Engineering and Technology,V-8,I-8,PP-1433-1443,Y-2017

32. Aswathy M.,Experimental study on light weight foamed concrete,International Journal of Civil Engineering and Technology,V-8,I-8,PP-1404-1412,Y-2017

33. Aswathy M.,Wastewater treatment using constructed wetland with water lettuce (Eichornia Crasipies),International Journal of Civil Engineering and Technology,V-8,I-8,PP-1413-1421,Y-2017

34. Kiruthiga K., Anandh K.S., Gunasekaran K, Assessment of influencing factors on improving effectiveness and productivity of construction engineers, 2015, International Journal of Applied Engineering Research, V - 10,I -17,p -13849-13854.

\section{AUTHORS PROFILE}

M.Hemapriya Assistant Professor, Department of Civil Engineering, Bharath Institute of Higher Education and Research, Chennai , India.

T.P.Meikandaan Associate Professor, Department of Civil Engineering, Bharath Institute of Higher Education and Research, Chennai , India

Anitha K Assistant Professor, Department of Civil Engineering, Bharath Institute of Higher Education and Research, Chennai, India. 